\title{
Analysis of the Influence Factors, Solutions, etc. on the Employment of Independent College Students Based on Social Capital Theory \\ - Take Jinqiao Independent College As an Example
}

\author{
Rui Dai \\ Oxbridge College, Kunming University of Science and technology, Kunming City, Yunnan Province \\ 650106
}

Keywords: Social capital; University student employment; Countermeasures

\begin{abstract}
In view of the influence of Social capital on the employment of college students, we propose countermeasures from the three levels of college students, families and schools, so that Social capital plays an important role in the employment process of college students.

In recent years, domestic government departments and schools have taken a lot of positive and effective measures to promote the employment of college students, but the employment situation of college students is still not satisfactory. Related research shows that social capital, like material capital and human capital, plays an important role in the employment process of college students, and they have unique properties and influences. Social capital can effectively help college students get employment information, so as to obtain employment opportunities and improve the quality of employment. Students, families, schools, etc. must fully understand the positive role of Social Capital. This paper proposes the use of social capital, so that social capital can play a major role in the employment of college students.
\end{abstract}

\section{College Level}

At present, many university graduates do not understand the positive role of "social capital" in the employment process and lack relevant theoretical knowledge. Some college students even think that "Using Social capital to 'help employment" means "bribery to others" and "get a connection". Therefore, college students should strengthen their study of the "social capital" theory in order to fully understand the function of Social capital. With the help of Social Capital, university graduates can gain employment confidence, broaden their employment channels, obtain jobs, and improve the quality of employment. It is very necessary to cultivate the consciousness of College students' Social capital, so that college students pay attention to the accumulation of Social capital in practice.

Discover "Ascription type of social capital". "Ascription type of social capital" refers to "social capital" that is determined by congenital factors such as gender, blood, genetics, and family background. Blood relationship is inborn and immutable. Each college student's "Ascription type of social capital" has its own characteristics. The influence of "Ascription type of social capital" on the employment choice of college students is very obvious, and it belongs to the category of "strong relationship". It also has stability and immutability. Therefore, kinship as a communication platform is easier to communicate and integrate. College students should fully understand their family relationships, especially other family relationships other than immediate family members. Under the assistance of parents, college students strengthen communication and contact with relatives through family gatherings and visits (in festivals), and thus maintain "Ascription type of social capital".

Expanding "self - induced social capital". From the time they received primary education to entering university, more than ten years, college students built social relationships with a large number of teachers, classmates, and friends, thus forming a network of interpersonal relationships. College students must not only maintain the original social relations, but also should establish good relationships with new teachers and new students during college, and gradually enhance the ability to make friends. College students should participate in social practice activities, part-time work, and internships, so as to expand the scope of interpersonal communication and expand self-induced 
social capital.

When constructing and accumulating Social capital, college students should demonstrate strong initiative and subjectivity, and actively and subconsciously pay attention to the increase and accumulation of Social capital, and optimize the structure of Social capital. Undergraduates should give full play to their subjective actions, continuously increase the level of Social capital, and increase the amount of Social capital, thereby realizing the value-added and accumulation of Social capital. College students should participate in community organization activities, social practice activities, etc., and in practice, exercise and enhance their organizational capabilities, collaboration capabilities, and communication skills. Students should also strengthen their "communication and exchanges with teachers and classmates." Expanding the scope of exchanges and expanding the network of social relationships among college students is conducive to enhancing university students' understanding and understanding of the society and achieving the goal of expanding "self-induced social capital".

Upgrading Human Capital, laying the foundation for Social Capital. The human capital refers to the stock of knowledge, habits, social and personality attributes, including creativity, embodied in the ability to perform labor as as to economic value. In the job hunting process, Human capital is a foundation, a hardware, and the like. Without a deep and solid knowledge and technology as a guarantee, social capital cannot play a positive role.

In the process of career selection, as the recruitment environment becomes more open and transparent, even if college students have obtained employment information through very good social relations and have used the social network to obtain job-search recommendations, if the university students cannot meet the "recruitment requirements" "Conditions," such as strong technical capabilities, are still unlikely to be obtained.

University students have excellent "Human capital", which helps to expand the social network. For example, if a college student wants to become a party member, a student cadre, etc., he will need to play a role as a "pioneer model" in actual activities. For example, in schools, excellent academic performance and high overall quality are the direct manifestations of human capital. "Birds of a feather flock together." To get better social relations, you must first become a good person. Only if the college students have excellent human capital can they attract the attention of others and help expand the social network.

\section{The Family Should Focus on Enhancing the Strength of Social Capital}

The family background is "Ascription type of social capital". Family relationships are "strong relationships" and are the most reliable relationships. However, the social capital involved in family relations reflects a small range and is not easily changed. Every family has a "circle" of social relations. The size of this "circle" is the scale of social capital owned by its family. This "circle" of social relations requires family members to jointly maintain and expand. Family members should build this social network based on the principles of mutual benefit, trust, and participation, so as to create a harmonious family social capital. The family raises the level of Social capital, develops external connections, expands the social network of family relationships, strives to increase the economic and social status of the family, and increases the strength of Social capital. Research shows that among the multiple factors that affect the employment of college students in the family background, the higher the parents' income and the more abundant family economic resources, the more economic resources the college students can use. Therefore, parents can help their children find employment through hard work, promotion of posts, and increased income.

\section{Schools should make Overall Plans, Highlight Features, and Expand Social Networks}

For schools, they should also have sufficient knowledge of the important role of Social capital in the employment of college students and pay close attention to it. Based on the characteristics of Independent College's own education, it fully mobilizes and utilizes the functions of Social Capital to actively promote the employment of college students. 
Raising the Brand Image of Independent College and Expanding the Social Network of Independent College. The brand of colleges and universities is an image effect and represents the recognition and trust of society. From the perspective of the employing department, graduates of prestigious universities represent high-quality talents. The employing department recruits and recruits graduates of prestigious universities. This not only means that the employing department employs Human Capital of the prestigious universities, but also that the employing department can use the reputation of prestigious universities to promote their image. Therefore, the promotion of the brand image of the college and the promotion of the fame of the college is more conducive to the communication and exchange between the college and the employing department, and is conducive to the expansion of the social network. The establishment of a college brand will not be overnight, but it will require the continuous efforts of several generations. Compared to first-batch and second-batch universities, Jinqiao Independent College was established for a relatively short period of time and has a weak foundation. However, Jinqiao Independent College has a flexible management system, a complete market-based operating mechanism, and unique location advantages. Therefore, in the market economy, Jinqiao Independent College can respond to supply and demand information in the job market more quickly and more acutely. At present, China is vigorously developing cooperative relations with countries in Southeast Asia and South Asia. Kunming University of Science and Technology Jinqiao Independent College seized this opportunity, relied on the location advantages of Yunnan Province, adjusted the idea of running schools, added specialties, and focused on cultivating students with international exchanges with "Southeast Asian countries and South Asian countries". In recent years, Jinqiao Independent College has also established close cooperation with more than 80 universities and educational institutions abroad, such as the Massachusetts Institute of Technology (USA), Chiang Mai University (Thailand), and Swansea University (UK). Jinqiao Independent College's international cooperation and exchange programs have been increasing year by year. The number of teachers and students exchanged and received by the school each year exceeds 1,000, and there are more than 50 fixed joint education programs. The "open style" school running characteristics are very prominent, and it has greatly improved the college brand, thereby expanding the college's social network and increasing the employment rate of college students.

Attach Importance to Employment Guidance and Focus on Cultivating the Awareness of University Students in Accumulating Social Capital. Currently, Jinqiao Independent College has set up courses related to employment guidance, including "University Students Entrepreneurship Education", "College Career Planning", and "College Students KAB Education - China Project". However, the core content of these courses is focused on entrepreneurial ideas, entrepreneurial planning, etc., neglecting the education on social capital theory. Therefore, Jinqiao Independent College needs to set up a social capital theory program to provide students with a detailed, in-depth and systematic introduction to the functions of social capital, social relations, and social resources in the employment process, and to guide college students in cultivating social goals. Capital awareness, at the same time, allows college students to discover, cultivate and accumulate their own social capital.

Actively Construct Social Practice System for College Students. The social practice of college students can use and test the situation of the theoretical knowledge they have learned in the actual application process. More importantly, the social practice of college students can exercise and cultivate the college students' practical ability to operate, creativity, organizational management, social skills, and the ability of adaptability. In the social practice, college students upgrade their "Human capital" and develop and enhance their social skills, thereby expanding their social network. Jinqiao Independent College has always focused on students' social practices. Jinqiao Independent College integrated the resources of the school and the investor and established the "University Science and Technology Park", "Science and Technology Entrepreneurship Base for College Students", "University Venture Demonstration Park", and "Students KAB Entrepreneurship Club". Wide-ranging cooperation with "schools and enterprises overseas and beyond the province" has been widely carried out outside the school, especially with the various types of second-tier 
companies affiliated with (investors) Yunnan CSJS Investment Co., Ltd. Jinqiao Independent College has built a comprehensive social practice system to enhance students' human capital and cultivate their social capital.

Play the Cohesive Role of Teachers. At present, the domestic labor market is still in a transitional period. Under such circumstances, teachers, as educators, are an important "link" between students and schools. Teachers can play a significant role in cohesion. Teachers should clearly understand the school's "Social capital" and make full use of the school's social network. Teachers can also expand their "Social capital" by actively linking with previous graduates to help students find employment. On the other hand, teachers should fully and comprehensively understand and master the real situation of students. Teachers should also guide students to fully understand their "Social capital" and bring their own subjective initiatives into play so as to help students accumulate, Add "Social capital" and realize the positive role of "Social capital" in the employment process.

\section{References}

[1] Zheng Jie: Family socio-economic status and employment of university students: From the perspective of Social capital [J]. Journal of Beijing Normal University (Social Sciences Edition), 2004 (3)

[2] Lu Shuguang: Research on the relationship between social capital and the employment of college students majoring in sports [D]. Master thesis of Henan University, 2006

[3] Hu Ningwei: Empirical study on the relationship between social capital and employment of college students [D]. Master thesis of Central South University, 2010

[4] Yu D, Peng L. When does Inferring Reputation Probability Countervail Temptation in Cooperative Behaviors for the Prisoners' Dilemma Game? [J]. Chaos, Solitons \& Fractals, 2015, 78: 238-244. 